\title{
Inclusion of palliative care teaching in medical schools in Brazil
}

\author{
Cuidados paliativos: inserção do ensino nas escolas médicas do Brasil
}

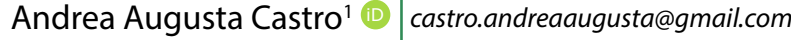 \\ Stella Regina Taquette ${ }^{1}$ (D) stella.taquette@gmail.com \\ Natan lório Marques' 1 (D) nataniorio19@gmail.com
}

\begin{abstract}
Introduction: The palliative care (PC) approach is a care modality recommended by the World Health Organization. Suffering and the process of dying are present in everyday clinical practice, affecting people with life-threatening diseases. However, the predominant model of teaching in Brazilian medical schools does not include palliative care.

Objectives: The aim of the study was to get to know the Brazilian medical schools that include PC in their curriculum, and how it has been taught.

Methods: Descriptive and exploratory study, carried out by searching for medical schools with disciplines in PC, through the analysis of the course syllabi available in the curricular matrices on the official websites of higher education institutions from August to December 2018. They were analyzed considering the offered period of the PC content, workload, scenario, and type of discipline (elective or mandatory).

Results: 315 schools registered with the Ministry of Education were found, and only 44 of them (14\%) offer courses in PC. These schools are distributed throughout 11 Brazilian states, of which 52\% are located in the Southeast region, 25\% in the Northeast, 18\% in the South, 5\% in the Midwest, and none in the North region. The predominant modality of the type of discipline in PC was mandatory in $61 \%$ of schools. Most Brazilian medical schools are private entities (57\%), a similar percentage to the total number of medical schools identified with the teaching of PC. This course takes place in the $3^{\text {rd }}$ and $4^{\text {th }}$ years of the course; in most schools, the workload was 46,9 hours. The predominant scenario is the classroom, while some institutions provide integration between teaching community service and medical practice. The program contents are diverse, including thanatology, geriatrics and finitude, humanization, bioethics, pain, oncology and chronic diseases.
\end{abstract}

Conclusion: PC education in Brazil is insufficient, which represents a barrier to the training of doctors in line with the recommendations of international entities, the National Curriculum Guidelines and legal frameworks within the scope of SUS. Investments by medical entities and government agencies are necessary to increase teaching in PC and the consequent qualification of medical training.

Keywords: Palliative Care; Medical Education; Thanatology; Curriculum.

\section{RESUMO}

Introdução: Abordagem em cuidados paliativos (CP) é uma modalidade assistencial recomendada pela Organização Mundial da Saúde. O sofrimento e o processo de morrer estão presentes no cotidiano da prática clínica, acometendo pessoas portadoras de doenças ameaçadoras à vida. Entretanto, o currículo predominante das escolas médicas brasileiras não inclui o ensino de CP.

Objetivos: Este estudo teve como objetivos conhecer os cursos de Medicina brasileiros que incluem CP em sua grade curricular e verificar de que forma estes vêm sendo ministrados.

Métodos: Trata-se de estudo descritivo e exploratório realizado por meio da busca de cursos de Medicina com disciplinas de CP nos sítios virtuais oficiais das instituições de ensino superior, no período de agosto a dezembro de 2018, e da análise das ementas disponíveis nas matrizes curriculares, no que diz respeito ao período oferecido, à carga horária, a cenário e ao tipo de disciplina, se eletiva ou obrigatória.

Resultados: Das 315 escolas de Medicina cadastradas no Ministério da Educação, apenas 44 cursos de Medicina (14\%) dispõem de disciplina de CP. Esses cursos estão distribuídos em 11 estados brasileiros, 52\% estão na Região Sudeste, 25\% na Região Nordeste, 18\% na Região Sul, 5\% na Região Centro-Oeste, e nenhum na Região Norte. A modalidade predominante do tipo de disciplina foi obrigatória em $61 \%$ das escolas. Em relação à natureza, $57 \%$ são entidades privadas, percentual semelhante ao total de escolas médicas brasileiras. A disciplina ocorre no terceiro e quarto anos do curso, na maioria das instituições, e a carga horária mediana foi 46,9 horas. O cenário predominantemente é a sala de aula, e algumas instituições proporcionam a integração ensino-serviço-comunidade e prática médica. Os conteúdos programáticos são variados, incluindo tanatologia, geriatria, senescência e finitude, humanização, bioética, dor, oncologia e doenças crônicas.

Conclusão: $O$ ensino de CP no Brasil é escasso, o que representa uma barreira à formação de médicos em consonância com as recomendações das entidades internacionais, das Diretrizes Curriculares Nacional e de marcos legais no âmbito do SUS. Fazem-se necessários investimentos das entidades médicas e dos organismos governamentais para a ampliação do ensino de CP e a consequente qualificação da formação médica.

Palavras-chave: Cuidados Paliativos; Educação Médica; Tanatologia; Currículo.

${ }^{1}$ Universidade do Estado do Rio de Janeiro, Rio de Janeiro, Rio de Janeiro, Brazil.

Chief Editor: Daniela Chiesa

Associate Editor: Kristopherson Lustosa Augusto

Received on 08/19/20; Accepted on em 02/17/21.

Evaluated by double blind review process. 


\section{INTRODUCTION}

Current societies face challenges in the health area due to the prolongation of life expectancy, with a consequent increase in the prevalence of chronic-degenerative diseases due to the population's aging process. On the other hand, according to data from the World Health Organization (WHO), this reality brings up the importance of including in medical education topics related to end-of-life care and the process of dying. Emerging diseases, such as COVID19, combined with demographic and epidemiological transitions, require specific care processes during illness and death. People who are undergoing the process of finitude, whether in acute processes or those with advanced diseases, can benefit from the palliative care (PC) approach, corroborated by scientific evidence. Adequate support from professionals with PC resources requires rethinking the role of medical schools aiming to meet the health needs of patients and families ${ }^{1-4}$.

The PC approach emerges from a historical and sociocultural process, with the medieval hospices, places of lodging destined to accommodate people who needed care due to illness or hunger, as examples of this modality. However, it was only in the 1960s that modern palliative care emerged. Two health professionals, Cicely Saunders in the United Kingdom and Elizabeth Kübler-Ross in Switzerland/USA promoted the teaching and research in PC, aiming at best practices for people who needed assistance in the finitude of life ${ }^{5,6}$.

In Brazil, the pioneering work of Professor Marco Túlio A Figueiredo has been recorded, by creating an elective course in PC for students at Universidade Federal de São Paulo from 1994 to 2008. According to Oliveira et $\mathrm{al}^{7}$, when evaluating the teaching of bioethics and PC, there is a fragile commitment of Brazilian medical schools in relation to PC teaching.

The approach in PC can be understood as a care modality recognized as adequate for children and adults in situations of suffering and with life-threatening diseases, as well as their families. They must be offered to people whose conditions lead to a high risk of mortality, negative impact on quality of life and implications for body functions. PC take the individual into account as a whole, regarding the physical, psychological, social and spiritual aspects, and not just their illness. For the PC to be effective, they require interprofessional and interdisciplinary work to manage symptoms and prevent complications ${ }^{8,9}$.

The intensification of PC training is relevant in teaching since undergraduate school, being a strategy that corroborates for de-hospitalization and greater user satisfaction. PC teaching, when included in the undergraduate course, captures the attention of future doctors, improving the care offered to the patient. A greater sense of control is observed in the interaction with patients and family members, as well as compassion, empathy and respect, through exposure to patients with advanced diseases ${ }^{10,11}$.

It is observed that curriculum presentations vary considerably worldwide, even in countries where palliative medicine has become mandatory in undergraduate medical courses. According to Von Gunten et $\mathrm{al}^{12}$ and Schulz et $\mathrm{al}^{13}$, changes in attitudes are important challenges, requiring the interchanging of didactic and experiential strategies, enhanced by self-reflection and interdisciplinary teaching to achieve the competencies required for the PC learning process.

PC competencies are aligned with patient-centered care and respect for autonomy, as well as family approach. These involve technical, cultural and ethical issues, such as the decrease in inappropriateand littleeffective use of invasive medical intervention to the detriment of resources to improve the quality of life and the dealing with the process of death in human existence ${ }^{14,15}$.

According to the international literature, the evaluation of PC teaching have shown changes in students' values and attitudes, and are recognized as essential for medical training, contributing to the acquisition of communication skills, as well as the examination of the patient's preferences regarding end-of-life care, the relaying of bad news and the conversation about spiritual issues and their practices ${ }^{16-18}$.

According to MacPherson et $\mathrm{al}^{19}{ }^{19}$ PC teaching should be integrated into the undergraduate curriculum, enabling better symptom management, teamwork and care with a focus on the person since the initial stages of illness.

According to Toledo et $\mathrm{al}^{20}$, there is little data on PC education in Brazil and a scarce literature corroborates this scenario. The authors comment on the identification of barriers in PC teaching and point out the challenges faced by the coordinators of medical courses, such as the lack of specialized teaching staff, the absence of clinical PC service, reduced interest by the institution, negligible funds, scarcity of time and of appropriate didactic material.

Considering these data, PC teaching is a necessity for the training of qualified doctors. This situation raises the following questions:

- How is PC teaching currently in Brazilian schools?

- Which pedagogical projects guide the training of health professionals focused on care, transforming the focus of attention from cure to care?

This study aims to identify the Brazilian medical courses that include PC in their curriculum, and how it has been taught.

\section{METHODS}

This is a descriptive, exploratory and cross-sectional study with a quantitative approach, which used secondary 
data on medical schools that included PC teaching in Brazil. The research field is concentrated in medical schools that have PC teaching in their curriculum. It started by searching for all medical schools registered in the official Brazilian database, available on the electronic system of the Ministry of Education of Brazil (e-Mec Register of Higher Education Institutions and Courses), and available medical school websites (www. Escolasmedicas.com.br) ${ }^{21,22}$. Subsequently, the websites of each school were consulted for the analysis and selection of the ones that have a palliative care discipline in the curricular matrix, from August to December 2018. Aiming to identify which schools have the PC discipline in their curricular matrix, the following topics were used in the search: palliative care, thanatology, processes of death, finitude and death, oncology and $P C$, geriatrics and $P C$, aging and death.

The distribution profile of the schools was analyzed regarding: Administrative Region and Federation Units (FU): number of vacancies offered in the $1^{\text {st }}$ year; type of institution, whether public or private; and among public ones, the type of administration, whether federal, state or municipal. The same profile analysis was carried out in relation to medical courses that have a PC discipline in their curricular matrix. To analyze the syllabi of the offered disciplines, we used the variables: period offered, workload, practice scenario, type of discipline (elective or mandatory) based on the recommendations of international entities for the teaching in palliative care and the 2014 National Curricular Guidelines for Medical Courses ${ }^{23,24}$.

\section{RESULTS}

We identified 315 medical schools in operation in Brazil during the assessed period. As for the geographic distribution, $42.5 \%$ are located in the Southeast, $16.5 \%$ in the South, $8.9 \%$ in the Midwest, $23.9 \%$ in the Northeast and $8.2 \%$ in the North region. The schools are distributed throughout all Brazilian states, with most of them being private schools (63.8\%). Approximately 33,520 vacancies were made available for the first year of medical courses in 2018, almost half (46\%) in the Southeast region, as shown in Table 1.

There were 114 public medical schools (36.2\%). In the states of Amapá and Roraima, 100\% of medical schools are public. Most medical schools are private (201), totaling 105 (52\%) courses, all of them located in the Southeast region.

As for the teaching of PC, we identified 44 medical schools that have the discipline of PC in their curricular matrix, as shown on the official websites of educational institutions, which corresponds to $14 \%$ of the total number of schools, and $16 \%$ of the total number of vacancies offered for $1^{\text {st }}$ year of medical school. The distribution of these schools according to the Region, Federation Unit (FU), number of vacancies offered in the first year and the type of the institution are shown in Table 2. It is worth noting that there are no medical courses in the North region of the country that offers training in PC. On the other hand, the predominance of schools with the discipline of PC (52\%) is also located in the Southeast region.

Table 1. Distribution of medical schools according to geographic distribution (Region-FU), number of vacancies in the $1^{\text {st }}$ year and type of institution, Brazil-2018

\begin{tabular}{|c|c|c|c|c|c|c|}
\hline \multirow{2}{*}{ Region } & \multirow{2}{*}{ FU } & \multirow{2}{*}{$\begin{array}{c}\mathrm{N} . \text { of } \\
\text { vacancies }\end{array}$} & \multicolumn{2}{|c|}{$\begin{array}{l}\text { Public } \\
\text { schools }\end{array}$} & \multicolumn{2}{|c|}{$\begin{array}{l}\text { Private } \\
\text { schools }\end{array}$} \\
\hline & & & $\mathrm{n}$ & $\%$ & $\mathrm{n}$ & $\%$ \\
\hline \multirow{8}{*}{ NORTH } & PA & 690 & 4 & 67 & 2 & 33 \\
\hline & AM & 465 & 3 & 60 & 2 & 40 \\
\hline & RO & 325 & 1 & 25 & 3 & 75 \\
\hline & $A C$ & 161 & 1 & 50 & 1 & 50 \\
\hline & AP & 60 & 1 & 100 & 0 & 0 \\
\hline & TO & 518 & 2 & 33 & 4 & 67 \\
\hline & $\mathrm{RR}$ & 140 & 2 & 100 & 0 & 0 \\
\hline & Total & 2,359 & 14 & 60 & 12 & 40 \\
\hline \multirow{10}{*}{ NORTHEAST } & BA & 2,164 & 11 & 52 & 10 & 48 \\
\hline & PE & 1,490 & 6 & 55 & 5 & 45 \\
\hline & PB & 985 & 3 & 33 & 6 & 67 \\
\hline & CE & 1,093 & 4 & 50 & 4 & 50 \\
\hline & $\mathrm{PI}$ & 631 & 5 & 71 & 2 & 39 \\
\hline & $\mathrm{RN}$ & 472 & 2 & 40 & 3 & 60 \\
\hline & MA & 539 & 2 & 33 & 4 & 67 \\
\hline & $A L$ & 495 & 2 & 40 & 3 & 60 \\
\hline & SE & 320 & 2 & 67 & 1 & 33 \\
\hline & Total & 8,189 & 37 & 49 & 38 & 51 \\
\hline \multirow{5}{*}{ MIDWEST } & GO & 1,374 & 4 & 31 & 9 & 69 \\
\hline & DF & 336 & 2 & 50 & 2 & 50 \\
\hline & MT & 431 & 4 & 67 & 2 & 33 \\
\hline & MS & 388 & 4 & 80 & 1 & 20 \\
\hline & Total & 2,529 & 14 & 47 & 14 & 53 \\
\hline \multirow{5}{*}{ SOUTHEAST } & $S P$ & 7,300 & 9 & 15 & 51 & 85 \\
\hline & MG & 4,787 & 14 & 30 & 32 & 70 \\
\hline & RJ & 2,789 & 5 & 23 & 17 & 77 \\
\hline & ES & 718 & 1 & 17 & 5 & 83 \\
\hline & Total & 15,594 & 29 & 22 & 105 & 78 \\
\hline \multirow{4}{*}{ SOUTH } & PR & 2,139 & 9 & 45 & 11 & 55 \\
\hline & SC & 957 & 4 & 33 & 8 & 67 \\
\hline & RS & 1,753 & 7 & 35 & 13 & 65 \\
\hline & Total & 4,849 & 20 & 38 & 32 & 62 \\
\hline Overall total & & 33,520 & 114 & 36 & 201 & 64 \\
\hline
\end{tabular}


Of the 44 institutions that included the palliative care discipline in the curriculum, it is mandatory in 27 schools (61\%) and elective in 17 schools (39\%).

In most schools, PC training occurs in the clinical cycle (3rd and 4th years) with a median workload of 46.9 hours, varying from $18 \mathrm{~h}$ to $119 \mathrm{~h}$ (Chart 1). Schools that follow a modular curriculum were excluded from the estimate. The most frequent

Table 2. Distribution of medical schools with the PC discipline according to the geographic distribution (RegionFU), number of vacancies in the 1st year and type of institution, Brazil-2018

\begin{tabular}{|c|c|c|c|c|c|c|}
\hline \multirow[t]{2}{*}{ Region } & \multirow[t]{2}{*}{ FU } & \multirow[t]{2}{*}{$\begin{array}{c}\text { N. of } \\
\text { vacancies }\end{array}$} & \multicolumn{2}{|c|}{$\begin{array}{l}\text { Public } \\
\text { Schools }\end{array}$} & \multicolumn{2}{|c|}{$\begin{array}{l}\text { Private } \\
\text { Schools }\end{array}$} \\
\hline & & & $\mathbf{n}$ & $\%$ & $\mathrm{n}$ & $\%$ \\
\hline \multirow{4}{*}{ NORTHEAST } & BA & 525 & 3 & 50 & 3 & 50 \\
\hline & CE & 460 & 2 & 50 & 2 & 50 \\
\hline & $\mathrm{RN}$ & 80 & 1 & 100 & 0 & 0 \\
\hline & Total & 1,065 & 6 & 55 & 5 & 45 \\
\hline \multirow{2}{*}{ MIDWEST } & MS & 140 & 2 & 100 & 0 & 0 \\
\hline & Total & & 2 & 100 & 0 & 100 \\
\hline \multirow{5}{*}{ SOUTHEAST } & SP & 986 & 4 & 67 & 2 & 33 \\
\hline & MG & 945 & 1 & 17 & 5 & 83 \\
\hline & RJ & 1,309 & 2 & 22 & 7 & 78 \\
\hline & ES & 228 & 2 & 50 & 2 & 50 \\
\hline & Total & 3,468 & 7 & 28 & 16 & 64 \\
\hline \multirow{4}{*}{ SOUTH } & PR & 620 & 3 & 50 & 3 & 50 \\
\hline & SC & 100 & 1 & 100 & 0 & 0 \\
\hline & RS & 100 & 0 & 0 & 1 & 100 \\
\hline & Total & 820 & 4 & 50 & 4 & 50 \\
\hline Overall Total & & 5,493 & 19 & 43 & 25 & 57 \\
\hline
\end{tabular}

teaching scenario is the classroom, that is, a predominantly theoretical approach. Scenario diversity was observed in seven institutions, with a service-school-community teaching model and medical practice. PC teaching is part of the modular model (workload > 120h) in twelve schools, consisting of theory and practice, but a specific PC workload cannot be identified. In two schools, PC is included in more than one moment of the course as a discipline. The syllabi were not available in two of the schools, but only appeared as being part of the curricular matrix. As shown in the programs of the assessed schools, the predominant contents were thanatology, geriatrics, senescence and finitude, humanization, ethics-bioethics, pain, oncology and chronic diseases.

\section{DISCUSSION}

The present study shows that the geographic distribution of medical schools that offer PC teaching is similar to that of total number of schools in the country, with the exception of the North region, which has no schools that include PC as a discipline. The highest concentration of medical courses is found in the Southeast region, which may be an indicator of the country inequalities (Table 2).

When we observe the distribution of schools that have PC teaching throughout the Brazilian states, greater investment is verified in some states. It is observed that $50 \%$ of the schools in the state of Ceará and $41 \%$ of the schools in the state of Rio de Janeiro have a PC discipline. In the state of Mato Grosso do Sul, $40 \%$ of the medical schools have a PC discipline. On the other hand, in the state of São Paulo, 10\% of the schools have a PC discipline. Inter and intra-regional differences are evident. In the Southern region of the state of Paraná, 30\% of schools have a PC discipline and in the State of Rio Grande do Sul, only $5 \%$. This reality may reflect the legal frameworks to promote

Chart 1. Distribution of Palliative Care discipline workloads in medical schools in Brazil - 2018.

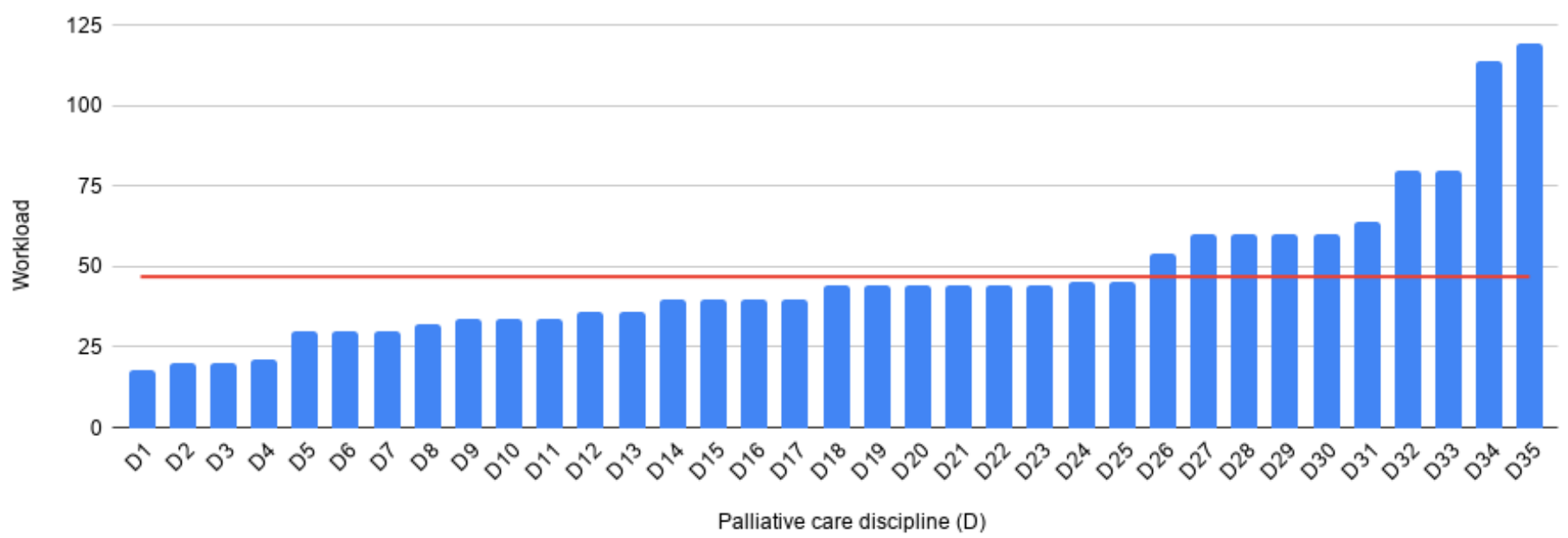


PC, both at the national and state levels. These are initiatives by the society and the state legislative power, as is the case of the states of Paraná and Rio de Janeiro, which reinforce the promotion of public policies for the reorganization of services and training of human resources in the field of $P C^{25-27}$.

Regarding the medical schools with a PC discipline, it can be observed that 25 (57\%) are private schools. This proportion in relation to the type of funding entity is also observed in the total of Brazilian medical schools, which reflects a trend towards the progression through the privatization in medical education, as described in the literature ${ }^{28}$.

International studies point to a worldwide consensus on the importance of teaching PC in undergraduate courses. However, its inclusion and the consolidation of the teachinglearning process is very different in each country and school. The realities are very different, considering the cultural, economic, political and social aspects. Although it is considered important, there are challenges for the inclusion of palliative care teaching worldwide. In Latin America, only 05 countries are officially certified in palliative care. In Brazil, palliative medicine is considered an area of activity ${ }^{29,30}$. In the USA, specific PC teaching is declared in three quarters of medical schools, a much higher percentage than that found in Brazil, where it was only identified in $14 \%$ of schools.

According to Floriani (2008), the importance of a teaching policy with continuing educational programs in PC is pointed out, in line with other experiences from around the world. The inclusion of the PC discipline can reduce distortions considering the curative therapeutic limitations, reinforcing the relationship of care and other non-curative approaches in advanced-stage diseases ${ }^{31,32}$.

According to Calda et $\mathrm{al}^{33}$, the challenges in implementing PC teaching can be attributed to the lack of knowledge about $P C$, generating resistance to changes, which persist due to the teaching staff's low level of training in this area of knowledge. On the other hand, the curricula have excessive workloads and limited resources.

The study program content found in the syllabus of Brazilian schools points to the domains recommended by scientific entities and national and international studies. Some schools emphasize thanatology and the study of death and dying; others address the life cycle as in geriatrics, senescence and finitude, and others in groups of more specific diseases, such as oncology and symptom management such as pain. According to MacPherson, the teaching should be integrated into the undergraduate curriculum, and it is recommended it should include areas of knowledge such as symptom control, teamwork and caring for the individual from the basic stages of illness ${ }^{34}$.
The Brazilian teaching experiences in PC have a median workload of 46.9 hours, consistent with the recommended one, although with variations in modular formats. According to international entities, such as the Worldwide Palliative Care Alliance (WPCA, 2014) and the recommendations of the National Academy of Palliative Care, the training of professionals can be divided into three levels, with basic training in PC being recommended in undergraduate school in all health areas, with the specific workload varying from 18 to 45 hours $\mathrm{s}^{35,36}$.

The literature recommends experience-based learning, which results in significant practice. According to Shaheen ${ }^{37}$, in the USA, the learned topics are taught by physicians from different specialties, such as geriatricians, family doctors in home care and clinicians in the wards. However, difficulties in teaching strategies are reported, with reading and discussion tactics in small groups still prevailing.

Regarding the learning scenarios, the integration between teaching-school-community and medical practice was observed in some Brazilian experiences. Considering the studies by Costa et al38, the transformations of students' representativeness about $\mathrm{PC}$, the time required for rationalization and awareness, and the acquisition of assertive skills such as symptom management, are enhanced by the theoretical reflection associated with the field of practice and interprofessional education.

This knowledge can be used in all areas of the future doctors' activities and specialties. For Gibbins et $\mathrm{al}^{39}$, the inclusion of PC teaching in undergraduate courses allows the student to develop skills that will improve patient care not only in terms of finitude, but also in general patient care.

According to Carroll et $\mathrm{al}^{40}$, there is a lack of standardization regarding the learning objectives and what should be taught in PC, as well as the fragmentation of teaching and/or its formal absence from the curricula. Different learning strategies can be included during the training of doctors in general PC, and not just as a specialty.

Although PC education in Brazil remains scarce, the data indicate that transformations are taking place in the country. Until 2012 , the country officially had 03 schools (2\%) with a palliative care discipline in its curriculum. The studies by Oliveira et $\mathrm{al}^{7}$ and Fonseca et $\mathrm{al}^{41}$ showed specific initiatives, albeit successful, in the PC area in some Brazilian schools in the state of Minas Gerais, São Paulo and Rio Grande do Sul. The occurrence of systematized PC teaching in 11 Federation Units and in most regions of Brazil shows the increase in PC teaching in Brazilian schools. According to a survey carried out by the National Academy of Palliative Care in 2017, there has been an increase from 40 PC teams to 123 PC services in the last fifteen years, and new studies are in progress, aiming at getting an update ${ }^{42}$. 


\section{CONCLUSION}

This study showed the increase in PC teaching in Brazil, although still insufficient, and a greater concern for the inclusion of a humanist axis, aiming at the acquisition of central competencies in the PC approach. We emphasize the need for this study to unfold into future investigations to assess the successful experiences in the area and the role of different social actors, expanding the knowledge of students' central roles, the strategies of the teachers involved in the process and the understanding of managers regarding the transformative potential of PC teaching.

Despite being limited to the information contained in the syllabi of the medical school curricular matrices, which are heterogeneous and sometimes reduced, our study reveals that the scarcity of PC teaching represents a barrier to the training of doctors, in agreement with the recommendations of international entities, the National Curriculum Guidelines and legal frameworks within the scope of SUS. The urgency of investments by medical entities and governmental bodies is evidenced for the expansion of PC teaching and the consequent qualification of medical training.

\section{AUTHORS' CONTRIBUTION}

Andrea Augusta Castro and Stella Regina Taquette participated equally in the study concept and design, acquisition, analysis and interpretation of the study results. Natan lório Marques participated in the acquisition and organization of data.

\section{CONFLICTS OF INTEREST}

The authors declare no conflicts of interest.

\section{SOURCES OF FUNDING}

The study was supported by FAPERJ, submitted to "Edital Faperj 12 / 2018- Programa apoio as Universidades Estaduais - UERJ, UENF and ENZO".

\section{REFERENCES}

1. Helman CG. Cultura, saúde \& doença. 4a ed. Porto Alegre: Artmed; 2003.

2. FAIMER. Consenso global das responsabilidades sociais das escolas médicas. 2012 [access in 3 nov 2017]. Available from: http:// healthsocialaccountability.sites.olt.ubc.ca/files/2012/02/GCSA-GlobalConsensus-document_portuguese.pdf.

3. Kelley AS. Defining serious illness. J Palliat Med. 2014;17(9):985. doi: 10.1089/jpm.2014.0164.

4. Gomes ALZ, Othero MB. Cuidados paliativos. Estud Av. 2016;30(88):15566. doi: 10.1590/S0103-40142016.30880011.

5. Twycross R. Medicina paliativa: filosofia e considerações éticas. Acta Bioeth. 2000;6(1):27:46. doi: 10.1590/S0103-40142016.30880011.

6. Floriani CA. Moderno movimento hospice: kalotanásia e o revivalismo estético da boa morte. Rev Bioét. 2013;21(3):397-404. doi: 10.1590/\$198380422013000300003.
7. de Oliveira JR, Ferreira AC, de Rezende NA. Ensino de bioética e cuidados paliativos nas escolas médicas do Brasil. Rev Bras Educ Med. 2013;37(2):285-90 [access in 20 mar 2018]. Available from: https://www. scielo.br/pdf/rbem/v37n2/17.pdf.

8. Burlá C, Py L. Cuidados paliativos: ciência e proteção ao fim da vida. Cad Saude Publica. 2014; 30(6):1-3. doi: 10.1590/0102-311XPE020614.

9. Bifulco VA, Lochida LC. A formação na graduação dos profissionais de saúde e a educação para cuidado de pacientes fora de recursos terapêuticos de cura. Rev Bras Educ Med. 2009;33(1):92-100 [access in 12 apr 2019]. Disponívelem:https://www.scielo.br/scielo. php?pid=S010055022009000100013\&script=sci_abstract\&tlng=pt.

10. Crawford GB, Zambrano SC. Junior doctors views of how their undergraduate clinical electives in palliative care influenced their current practice of medicine. Acad Med. 2015;90(3):338-44. doi: 10.1097/ ACM.0000000000000632.

11. Costa AP, Poles K, Silva AE. Palliative care education: experience of medical and nursing students. Interface (Botucatu). 2016;20(59):1041-52. doi: 10.1590/1807-57622015.0774.

12. Von Gunten CF, Mullan P, Nelesen RA, Soskins M, Savoia M, Buckholz G, et al. Development and evaluation of a palliative medicine curriculum for third-year medical students. J Palliat Med. 2012; 15(11):1198-217. doi: 10.1089/.jpm.2010.0502.

13. Schulz C, Möller MF, Seidler D, Schnell MW. Evaluating an evidence-based curriculum in undergraduate palliative care education: piloting a phase II exploratory trial for a complex intervention. BMC Med Educ. 2013;(4)13:1. doi:10.1186/1472-6920-13-1.

14. Silva MLSR. O papel do profissional da atenção primária à saúde em cuidados paliativos. Rev Bras Med Fam Comunidade. 2014;9(30): 45-53. doi: $10.5712 / \mathrm{rbmfc} 9(30) 718$.

15. Gibbins J, McCoubrie R, Maher J, Forbes K. Incorporating palliative care into undergraduate curricula: lessons for curriculum development. Med Educ. 2009;43(8):776-83. doi: 10.1111/j.1365-2923.2009.03400.x.

16. Parikh PP, White MT, Buckingham L, Tchorz KM. Evaluation of palliative care training and skills retention by medical students. J Surg Res. 2017;211:172 7. doi: 10.1016/j.jss.2016.11.006.

17. Simmenroth-Nayda A, Alt-Epping B, Gágyor I. Breaking bad news - an interdisciplinary curricular teaching-concept. GMS Z Med Ausbild. 2011;28(4):doc 52. doi: 10.3205/zma000764.

18. Sweeney C, Lynch G, Khashan A, Maher B, Murphy M, O'Brien T. The impact of a medical undergraduate student-selected module in palliative care. BMJ Support Palliat Care. 2014;4(1):92-7. doi: 10.1136/ bmjspcare-2012-000283.

19. MacPherson A, Lawrie I, Collins S, Forman L. Teaching the difficult-toteach topics. BMJ Support Palliat Care. 2014;4(1):87-91. doi: 10.1136/ bmjspcare-2012-000408.

20. Toledo AP, Priolli DG. Cuidados no fim da vida: o ensino médico no Brasil. Rev Bras Educ Med. 2012;36(1):109-17 [access in $13 \mathrm{sep}$ 2020]. Available from: https://www.scielo.br/scielo.php?pid=S010055022012000100015\&script=sci_abstract\&tlng=pt.

21. Brasil. Sistema e-MEC. Instituições de Educação Superior e Cursos Cadastrados. Brasília: MEC; 2017 [access in 17 dec 2017]. Available from http://emec.mec.gov.br/.

22. Nassif ACN. Escolas médicas do Brasil. São Paulo: Nassif; 2018 [access in 19 aug 2018]. Available from: http://www.escolasmedicas.com.br/estat.php.

23. Knaul FM, Farmer PE, Krakauer EL, De Lima L, Bhadelia A, Kwet JX, et al Alleviating the access abyss in palliative care and pain relief-an imperative of universal health coverage: the Lancet Commission report. Lancet 2017(7);391(10128):1391-444. doi: 10.1016/S0140-6736(17)32513-8.

24. Brasil. Resolução no 3, de 20 de junho de 2014. Institui Diretrizes Curriculares Nacionais do Curso de Graduação em Medicina e dá outras providências. Brasília: Ministério da Educação; 2014 [access in $16 \mathrm{apr}$ 2020]. Available from: http://portal.mec.gov.br/. 
25. Brasil. Resolução $n^{\circ} 41$, de 31 outubro de 2018. Dispõe sobre as diretrizes para a organização dos cuidados paliativos, à luz dos cuidados continuados integrados, no âmbito do Sistema Único de Saúde. Diário Oficial da União; 23 nov 2018. Seção 1, p. 276 [access in 17 mar 2020]. Available from: https://www.jusbrasil.com.br/diarios/218740387/dousecao-1-23-11-2018-pg-276.

26. Rio de Janeiro. Lei no 9449 , de 5 de julho de 2019. Dispõe sobre a criação do Programa Estadual de Cuidados Paliativos no âmbito do Estado do Rio de Janeiro. DOE; 8 jul 2019 [access in 17 mar 2020]. Available from: http:// alerjln1.alerj.rj.gov.br/scpro1519.nsf.

27. Assembleia Legislativa do Estado do Paraná. Lei no 20.091, de 19 de dezembro de 2019. Dispõe sobre a garantia de equipe multidisciplinar em cuidados paliativos. Diário Oficial; 19 dez 2019 [access in 20 mar 2020]. Available from: https://www.assembleia.pr.leg.br/comunicacao/noticias/ lei-garante-cuidados-paliativos-a-pacientes-com-doencas-graves-noparana.

28. Scheffer M, Cassenote A, Guilloux AGA, Biancarelli A, Miotto BA, Mainardi G, et al. Demografia médica no Brasil 2018. São Paulo: Departamento de Medicina Preventiva da Faculdade de Medicina da USP, Conselho Regional de Medicina do Estado de São Paulo, Conselho Federal de Medicina; 2018 [access in 17 mar 2020). Available from: https://jornal.usp.br/wp-content/ uploads/DemografiaMedica2018.pdf.

29. Pastrana T, De Lima L, Wenk R, Eisenchlas J, Monti C, Rocaforte J, et al. Atlas de Cuidados Paliativos na América Latina. Houston: IAPC; 2012. [access in 10 mar 2020]. Available from: https://cuidadospaliativos.org/ uploads/2014/1/Atlas\%20Portugues.pdf.

30. Conselho federal de Medicina. Resolução CFM no 1.973/2011. Dispõe sobre a nova redação do Anexo II da Resolução CFM no 1.845/08, que celebra o convênio de reconhecimento de especialidades médicas firmado entre o Conselho Federal de Medicina (CFM), a Associação Médica Brasileira (AMB) e a Comissão Nacional de Residência Médica (CNRM). Diário Oficial da União; $1^{\circ}$ ago 2011. Seção l, p. 144-7 [access in 13 mar 2020]. Available from: http://www.cremesp.org.br/?siteAcao=PesquisaLegislacao\&dif $=s \&$ ficha $=1 \& i d=9791 \&$ tipo $=$ RESOLU\%C7\%C3O\&orgao $=$ Consel ho\%20Federal\%20de\%20Medicina\&numero=1960\&situacao=VIGENTE\&data $=16-12-2010 \&$ vide $=$ sim.

31. Floriani CA. Palliative care in Brazil: a challenge to the health care system. Palliat Care. 2008;2: 19-24. doi: 10.1177\%2F117822420800200001.
32. Floriani CA, Schramm FR. Desafios morais e operacionais da inclusão dos cuidados paliativos na rede de atenção básica. Cad Saude Publica. 2007;23(9):2072-80. doi: 10.13140/2.1.3201.5367.

33. Caldas GHO, Moreira SNT, Vilar MJ Cuidados paliativos: uma proposta para o ensino da graduação em Medicina. Rev Bras Geriatr Gerontol. 2018;21(3):269-80. doi: 10.1590/1981-22562018021.180008.

34. MacPherson A, Lawrie L, Collins S, Forman L. Teaching the difficult-toteach topics. BMJ Support Palliat Care. 2014;4(1):87-91. doi: 10.1136/ bmjspcare-2012-000408.

35. World Health Organization. Global Atlas of Palliative Care at the end-oflife. Geneva: WHO, 2014. [access in 2 dec 2014]. Available from: http:// www.who.int/nmh/Global_Atlas_of_Palliative_Care.pdf.

36. Lehto JT, Hakkarainen $\mathrm{K}$, Kellokumpu-Lehtinen PL, Saarto $\mathrm{T}$. Undergraduate curriculum in palliative medicine at Tampere University increases students' knowledge. BMC Palliat Care. 2017; 16(1): 9-13 doi: 10.1186/s12904-016-0182-8.

37. Shaheen AW, Denton GD, Stratton TD, Hoellein AR, Chretien KC. End-of-life and palliative care curricula in internal medicine clerkships: a report on the presence, value, and design of curricula as rated by clerkship directors. Acad Med. 2014; 89(8):1168-73. doi: 10.1097/ACM.0000000000000311.

38. Costa AP, Poles K, Silva AE. Formação em cuidados paliativos: experiência de estudantes de medicina e enfermagem. Interface (Botucatu). 2016;20(59):1041-52. doi: 10.1590/1807-57622015.0774.

39. Gibbins J, McCoubrie R, Maher J, Wee B, Forbes K. Recognizing that it is part and parcel of what they do: teaching palliative care to medical students in the UK. Palliat Med. 2010;24(3):299-30. doi: 10.1177/0269216309356029.

40. Carroll T, El-Sourady M, Karlekar M, Richeson A. Primary palliative care education programs: review and characterization. Am J Hosp Palliat Care. 2019 June;36(6):546-49. doi: 10.1177/1049909118809947.

41. Fonseca A, Geovanini F. Cuidados paliativos na formação do profissional da área de saúde. Rev Bras Educ Med. 2013;37(1):120-5. doi: 10.1590/ S0100-55022013000100017.

42. Mendes EC. Cuidados paliativos e câncer: uma questão de direitos humanos, saúde e cidadania [dissertação]. Rio de Janeiro. Fundação Oswaldo Cruz, Escola Nacional de Saúde Pública Sergio Arouca, 2017 [access in 12 oct 2020]. Available from: https://www.arca.fiocruz.br/ bitstream/icict/24828/2/ernani_costa.pdf. 